\title{
Lessons from the RNA World: humility and hubris
}

\author{
MARVIN WICKENS \\ Department of Biochemistry, University of Wisconsin, Madison, Wisconsin 53706, USA
}

The research community I have lived in for the past 20 years, near the $3^{\prime}$ end of mRNAs, began as a small enclave of labs and now is a vibrant city full of them. The field has moved from outlines of how $3^{\prime}$ ends were formed to the biochemistry of all the components involved, and now includes mRNA regulation via $3^{\prime}$ UTRs, developmental controls, miRNAs, and networks of interacting mRNAs, non-coding RNAs and proteins.

These stunning developments in mRNA regulation have included beautiful biochemistry, genetics and biology. But perhaps what has brought me the most joy in RNA research is the sense that I am watching a Fellini film-or perhaps, to be a bit more contemporary, I should say a Harry Potter movie. Just when I think I know what is going on, onto the screen comes something entirely unexpected: self-splicing, miRNAs, riboswitches, new families of regulators, each amazingly different than any before. They burst through the door like Hagrid giving Dudley a pigtail.

There are important lessons to be learned from the recent past in the RNA World. Let us revisit the entrances of three players: miRNAs, RNAi, and CRISPR.

The discovery of miRNAs emerged from studies of a problem that developmental biologists long have been interested in-regulation of developmental timing. Of course, a layman might well consider this research at its esoteric worst-who could possibly care about when cells divide in a worm? But genetics on that esoteric problem led to a little RNA that regulated expression of a target gene by binding to its $3^{\prime}$ UTR. And then, a few years later, the deluge: the discovery of large numbers of miRNAs that regulate even larger numbers of genes, laid out in complex networks, with vital roles in physiology and disease.

In the history of RNAi, the first hints of something peculiar going on emerged from assays of the partitioning of components in early C. elegans morphogenesis. What were thought to be sense strands of RNA, injected into the worm as a con- trol for anti-sense RNA experiments, elicited inhibitory effects. The discovery that double-stranded RNAs were actually responsible for this inhibition came through compelling biochemistry, and led to an explosion of fascinating biology, and tools to manipulate gene expression and ask new questions in organisms previously out of reach.

CRISPR technology had its roots in studies of bacterial resistance to infectious agents. The work led to discovery of a bacterial immunity system, in which those bacteria became resistant to phage they or their ancestors had encountered. And now? Much elegant work later, look where we are: powerful manipulations that have transformed molecular genetics.

Two lessons are clear.

Humility is a virtue. We need to accept that we simply do not know what nature can offer us, and where it may lead. There are phenomena, molecules and cells-and RNAsthat we simply know nothing about and cannot even imagine. We need the first fortuitous glimpse, the accident that can come only through open eyed exploration.

And the corollary: hubris is destructive. To think we can now tackle problems using the technologies at hand and the suite of favored organisms is self-limiting. If ever we should embrace the diversity evolution has generated, it is now, with the powerful new methods like RNAi and CRISPR in hand.

Striking the right balance between exploratory and socalled "translational research," in which we target our work to applied ends, is a non-trivial issue, much discussed. But some conclusions seem inescapable from the last 20 years. We do not know what there is to find until we find it. No one could write a grant proposal to set out to discover miRNAs, RNAi, or CRSIPR without already having a reason to think they were there.

Humility before nature is power.
Corresponding author: wickens@biochem.wisc.edu

Article and publication date are at http://www.rnajournal.org/cgi/doi/ 10.1261/rna.050963.115. Freely available online through the RNA Open Access option.
(C) 2015 Wickens This article, published in RNA, is available under a Creative Commons License (Attribution-NonCommercial 4.0 International), as described at http://creativecommons.org/licenses/by-nc/4.0/. 

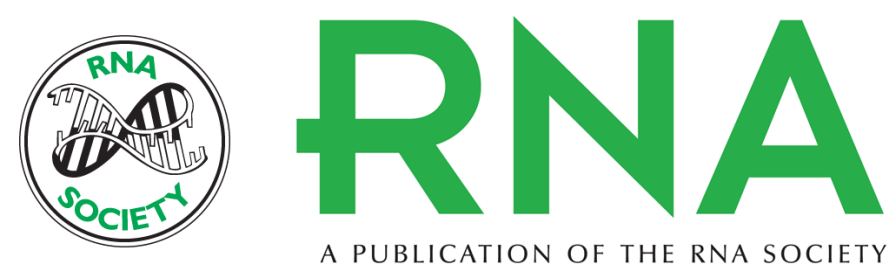

A PUBLICATION OF THE RNA SOCIETY

\section{Lessons from the RNA World: humility and hubris}

Marvin Wickens

RNA 2015 21: 482
Open Access Freely available online through the RNA Open Access option.
Creative This article, published in $R N A$, is available under a Creative Commons License Commons (Attribution-NonCommercial 4.0 International), as described at License http://creativecommons.org/licenses/by-nc/4.0/.

Email Alerting Receive free email alerts when new articles cite this article - sign up in the box at the Service top right corner of the article or click here.

To subscribe to RNA go to:

http://rnajournal.cshlp.org/subscriptions

(C) 2015 Wickens; Published by Cold Spring Harbor Laboratory Press for the RNA Society 